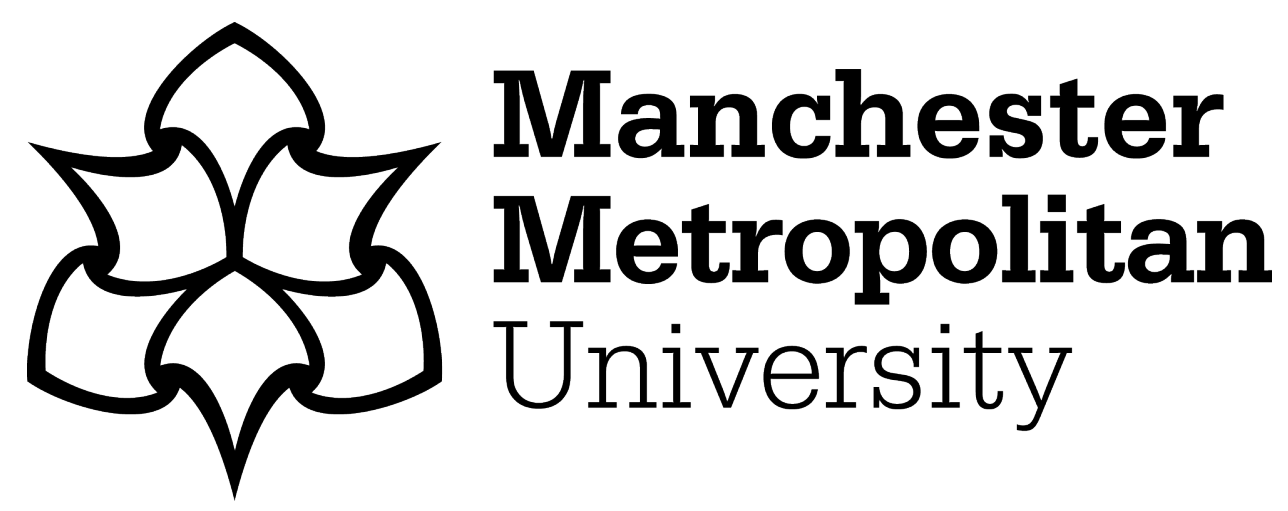

Phelps, Jacob, Aravind, Sakshi, Cheyne, Susan, Dabrowski Pedrini, Isabella, Fajrini, Rika, Jones, Carol A, Lees, Alexander C, Mance, Anna, Nagara, Grahat, Nugraha, Taufiq P, Pendergrass, John, Purnamasari, Umi, Rodriguez, Maribel, Saputra, Roni, Sharp, Stuart P, Sokolowki, Amir and Webb, Edward $L$ (2021) Environmental liability litigation could remedy biodiversity loss. Conservation Letters, 14 (6). e12821. ISSN 1755-263X

Downloaded from: https: //e-space.mmu.ac.uk/627929/

Version: Published Version

Publisher: Wiley

DOI: https://doi.org/10.1111/conl.12821

Usage rights: Creative Commons: Attribution 4.0

Please cite the published version 


\title{
Environmental liability litigation could remedy biodiversity loss
}

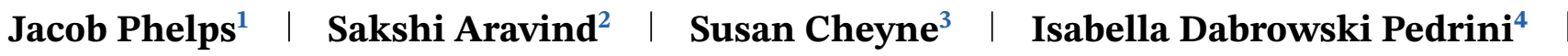 \\ Rika Fajrini $^{5}$ | Carol A. Jones ${ }^{6}$ | Alexander C. Lees ${ }^{7}$ | Anna Mance ${ }^{8}$ | \\ Grahat Nagara $^{9}$ | Taufiq P. Nugraha ${ }^{10}$ ｜ John Pendergrass $^{6}$ | Umi Purnamasari ${ }^{11}$ \\ Maribel Rodriguez $^{12}$ | Roni Saputra $^{13}$ | Stuart P. Sharp ${ }^{1}$ | Amir Sokolowki ${ }^{14}$ \\ Edward L. Webb ${ }^{15}$ \\ ${ }^{1}$ Lancaster Environment Centre, Library Avenue, Lancaster University, Lancaster, UK \\ ${ }^{2}$ Department of Land Economy, University of Cambridge, Cambridge, UK \\ ${ }^{3}$ School of Social Sciences, Oxford Brookes University, Headington, Oxford, UK \\ ${ }^{4}$ College of Administration and Economic Science (ESAG), Santa Catarina State University, Florianópolis, Santa Catarina, Brazil \\ ${ }^{5}$ Indonesian Center for Environmental Law (ICEL), South Jakarta, Indonesia \\ ${ }^{6}$ Environmental Law Institute, Washington, District of Columbia, USA \\ ${ }^{7}$ Ecology and Environment Research Centre, Department of Natural Sciences, Manchester Metropolitan University, Manchester, UK \\ ${ }^{8}$ Stanford Law School, Stanford University, Crown Quadrangle, Stanford, California, USA \\ ${ }^{9}$ Jentera Law School, Puri Imperium Office Plaza (UG) floor unit No. 15, Jl. Kuningan Madya No.RT.5, RT.1/RW.6, Guntur, Kecamatan Setiabudi, Kota \\ Jakarta Selatan, Daerah Khusus Ibukota, Jakarta, Indonesia \\ ${ }^{10}$ Research Center for Biology, Indonesian Institute of Science, Cibinong, West Java, Indonesia \\ ${ }^{11}$ Sajogyo Institute, Jl. Malabar No.22, RT.5/RW.07, Tegallega, Kecamatan Bogor Tengah, Kota Bogor, West Java, Indonesia \\ 12 Avenue Hof Ten Berg, Brussels, Belgium \\ ${ }^{13}$ Auriga Nusantara, Indonesia \\ ${ }^{14}$ Climate Kairos, London, UK \\ ${ }^{15}$ Department of Biological Sciences, National University of Singapore, Singapore
}

Correspondence

Jacob Phelps, Lancaster Environment Centre, Library Avenue, Lancaster University, Lancaster LA1 4YQ, UK.

Email:jacob.phelps@gmail.com

\begin{abstract}
Many countries allow lawsuits to hold responsible parties liable for the environmental harm they cause. Such litigation remains largely untested in most biodiversity hotspots and is rarely used in response to leading drivers of biodiversity loss, including illegal wildlife trade. Yet, liability litigation is a potentially ground-breaking conservation strategy to remedy harm to biodiversity by seeking legal remedies such as species rehabilitation, public apologies, habitat conservation and education, with the goal of making the injured parties 'whole'. However, precedent cases, expert guidance, and experience to build such conservation lawsuits is nascent in most countries. We propose a simplified framework for
\end{abstract}


developing conservation lawsuits across countries and conservation contexts. We explain liability litigation in terms of three dimensions: (1) defining the harm that occurred, (2) identifying appropriate remedies to that harm, and (3) understanding what remedies the law and courts will allow. We illustrate the framework via a hypothetical lawsuit against an illegal orangutan trader in Indonesia. We highlight that conservationists' expertise is essential to characterizing harm and identifying remedies, and could more actively contribute to strategic, science-based litigation. This would identify priority contexts, target defendants responsible for egregious harm, propose novel and meaningful remedies, and build new transdisciplinary collaborations.

\section{KEYWORDS}

civil law, compensation, conservation litigation, environmental governance, justice, lawsuit, natural resources

\section{1 | INTRODUCTION}

Biodiversity loss, driven by actions such as illegal wildlife trade, deforestation, pollution and mining, causes cascading ecological, social and economic harm (Díaz et al., 2020). These impacts place growing demands on legal systems to not only tighten regulations and strengthen enforcement, but also hold responsible parties liable for the harm they cause.

Although laws, procedures and practices vary among countries, many provide a legal right to remedy when the environment is harmed - including Brazil, China, Democratic Republic of Congo, European Union members, India, Indonesia, Mexico, Philippines and the United States (Jones et al., 2015; Rajamani, 2007). Yet, environmental liability litigation is virtually absent from practice across much of the Global South, including in many biodiversity hotspots. Moreover, such litigation is most familiar in the context of remedying pollution: Landmark cases, such as the 1989 Exxon Valdez and 2010 Deepwater Horizon oil spills, held responsible parties liable for remedying harms to both the general public and private parties by undertaking clean-up, habitat restoration and financial compensation (Cruden et al., 2016). However, these legal remedies have rarely been used to address key drivers of biodiversity loss, including illegal harvest, use and trade. We highlight how strategic liability litigation has groundbreaking potential to better safeguard biodiversity.

The body of precedent cases, expert guidance, and experience to build such conservation lawsuits is nascent in most countries. Characterizing environmental harm and identifying corresponding legal remedies is a longstanding challenge (BIOVAL, 2021; Boyd, 2010; Mazzotta et al, 1994; White \& Heckenberg, 2011), alongside difficul- ties in identifying defendants and establishing causal connections between their actions and the harm experienced (Bergkamp, 2001; Ruda González, 2006; Bentata \& Faure 2012). These are exacerbated by gaps between law and conservation; most conservationists lack legal training and are disengaged from legal discussions, beyond supporting criminal investigations of illegal trade (e.g., WCS, 2020). Moreover, litigation-related scholarship is published overwhelmingly in legal journals, and existing litigation is usually instigated by a small number of actors (e.g., Rajamani, 2007).

We explain how environmental liability litigation can be operationalized to serve biodiversity conservation in terms of three dimensions: (1) defining harm, (2) identifying appropriate remedies to that harm, and (3) understanding what remedies the law and courts will allow (Figure 1). We explain how litigation can help make injured parties 'whole' by providing remedies that return the harmed system as closely as possible to its baseline - its condition

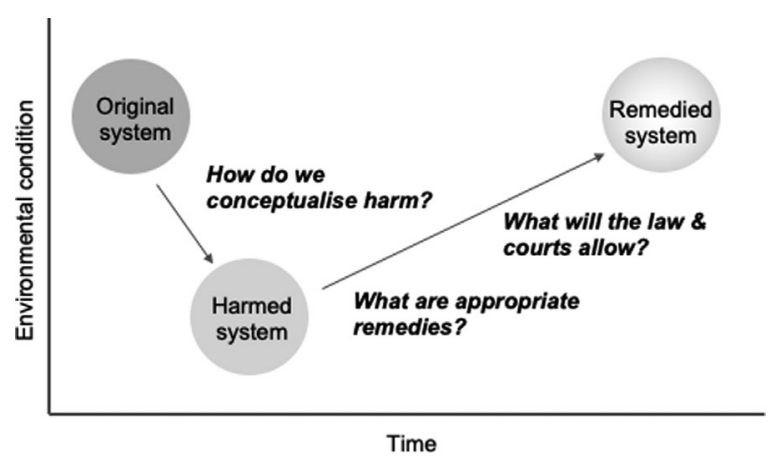

F I G U R E 1 Environmental liability litigation involves recognizing and evaluating harm, and then proposing remedies that laws and courts are able and willing to provide 
TA B L E 1 Example verdicts of criminal cases* for illegal wildlife trade in Indonesia that include orangutan (Pongo spp.) (Indonesia Supreme Court Database, http://putusan3.mahkamahagung.go.id/)

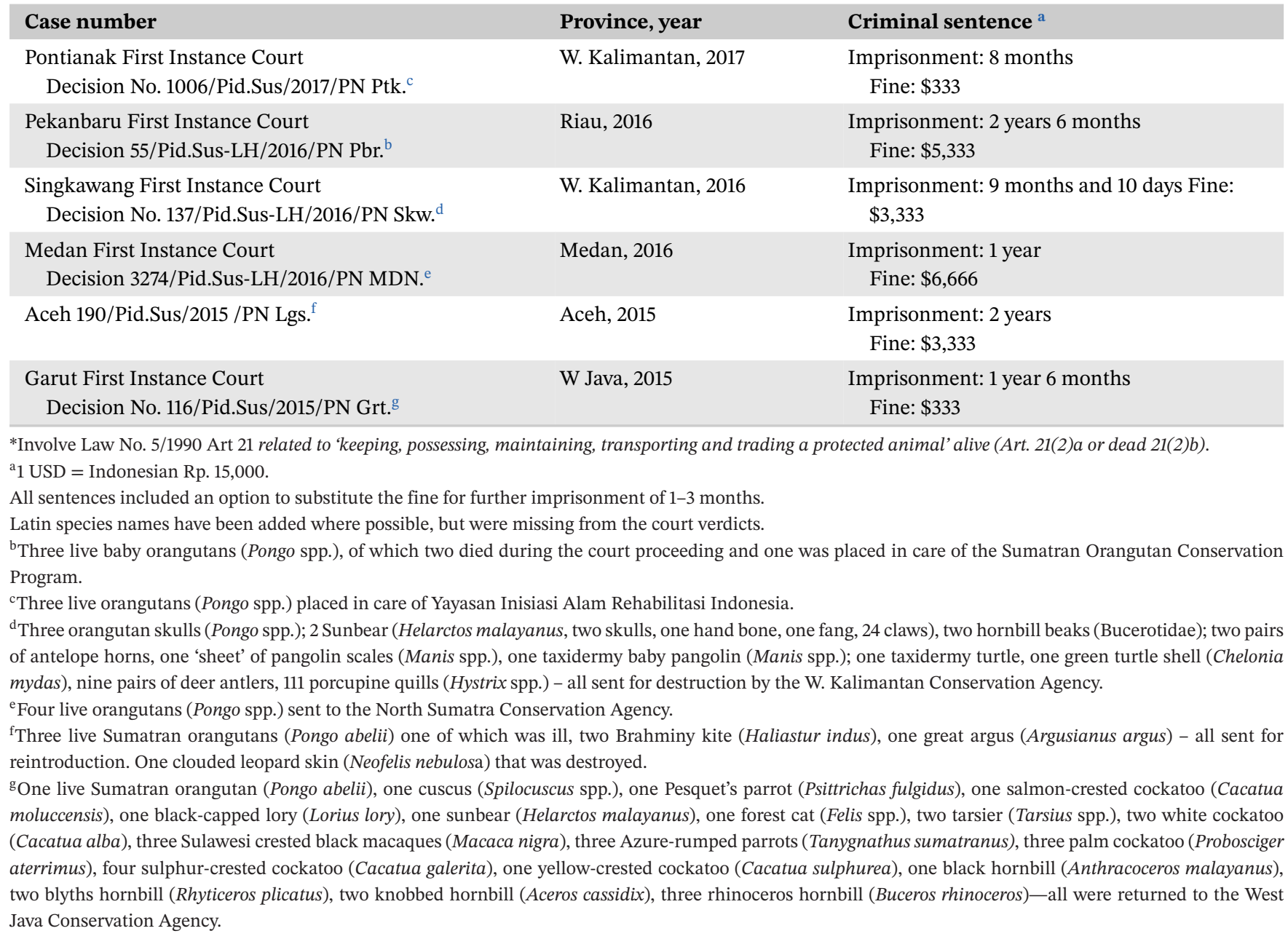

as though the harm had not occurred, and compensating for losses in the interim. Depending on jurisdiction, lawsuits can be brought by government agencies, individuals, NGOs and corporate plaintiffs, and seek remedies for harm experienced by both private parties (citizens, NGOs, companies, communities) and public resources (threatened species, protected areas, waterways). We explain how remedy-focused liability litigation is an important conservation strategy that creates new avenues for justice, and financial support for conservation. We propose a simplified framework that could help operationalize lawsuits across countries and contexts, illustrated through a hypothetical lawsuit against an illegal orangutan trader.

\section{1 | Liability litigation complements traditional conservation law approaches}

The conservation law toolkit includes a number of criminal, civil and administrative law responses, which vary spatiotemporally (e.g., Jones et al., 2015; Johnson et al., 2020).
Conservation typically draws on public law (i.e., administrative, criminal, constitutional, procedural law): government authorities dictate stakeholder obligations and prohibit certain acts, and impose fines and/or imprisonment sanctions designed to punish and deter (Cohen, 1991). For example, there has been a series of criminal case verdicts against the illegal trade of orangutan (Pongo spp.) in Indonesia (Table 1). However, fines and imprisonment often weakly reflect the harm that occurs in these cases, and sanctions are often considered too small to be deterrent, prompting efforts to strengthen sanctions and enforcement (e.g., UK, 2019, although see Wilson \& Boratto, 2020). Moreover, criminal justice systems often operate with their structural inequities undisturbed, disproportionately targeting poorer defendants against whom additional enforcement is unlikely to be proportionate, justified or effective (Wilson \& Boratto, 2020).

The conservation law toolkit also includes lawsuits (typically via civil or administrative law) in which individuals, NGOs or government agencies sue responsible parties in order to stop harmful actions (injunctions). Lawsuits may 
also be used to compel government agencies to take action, such as NGOs and citizens suing the US Fish and Wildlife Service to order enforcement of the Endangered Species Act (Brosi \& Biber, 2012).

In contrast, environmental liability litigation is distinct because it is focuses on remedying harm (Figure 1). Liability lawsuits uphold the principle that the person who causes a loss must bear the burdens of compensating the party that suffers it, as in the 'polluter pays' principle. Through litigation, plaintiffs can ask courts to order responsible parties to provide remedies such as habitat restoration, public apologies, species reintroduction, and financial compensation. These types of remedial actions are often possible under countries' civil law code, or administrative and criminal law in some jurisdictions. Importantly, liability litigation complements traditional criminal prosecutions, administrative sanctions, injunctive relief and orders to act, and defendants can be subject to overlapping legal processes. Moreover, liability litigation can be used strategically, focused on defendants who are most likely to command and sustain harm to biodiversity (e.g., organized criminal trafficking), and with the financial means to provide remedies.

We illustrate the potential for liability litigation to support conservation aims through a hypothetical liability lawsuit in Indonesia: A repeat, commercial wildlife trader was arrested for possessing and attempting to sell an infant, female Bornean orangutan (Pongo pygmaeus) that he procured and purchased from a rural farmer in West Kaliman$\tan$, Indonesia. The confiscated orangutan was transferred to a rehabilitation centre for future reintroduction into a managed population. The trader faces criminal sanctions for his illegal behaviour (fine, imprisonment, cf. Table 1), but a successful liability lawsuit would further force him to remedy the harm he caused. The scenario mirrors numerous criminal prosecutions against illegal wildlife traders, but lawsuits in this type of situation are virtually nonexistent (but see Marseille, 2020).

\section{2 | What is harmed when biodiversity is injured?}

Harm to biodiversity often involves impacts on individual plants, fungi and animals through acts such as wildlife trade or habitat destruction. Liability litigation involves identifying and explaining that harm. This can be challenging because biodiversity is multidimensional and impacts are often non-linear, cumulative and subject to time-lags (see Whitehead et al., 2017). Harm is also experienced as a function of the scale and nature of the illegal act, and how it affects species with different attributes (e.g., rarity, functional redundancy). Characterizing harm is further com- plicated because the linkages among biodiversity, ecosystems and human wellbeing are implicitly understood, but can be difficult to characterize and quantify for use in specific policy purposes (e.g., payment for ecosystem services, Hinsley et al., 2015). This is especially true when considering plural values for biodiversity, including those of Indigenous and traditional communities (e.g., Diaz et al., 2020), and plaintiffs' diverse eco-philosophical orientations, ontologies and approaches to justice (see Brisman $\&$ South 2018). There are also growing demands for new forms of legal rights, including the rights of nature (see Gordon, 2018). This complexity presents challenges for explaining harm, and thus developing lawsuits.

We illustrate four broad types of harm likely to occur when biodiversity is injured (Table 2). These include a range of public and private costs, and impacts that are financial and non-financial, material and intangible, proximate and more distal. A clear understanding of the types of harm incurred is a step in evaluating whether and how litigation can be pursued.

\subsection{What remedies correspond to different harms?}

Liability litigation explicitly focuses on identifying appropriate, fair remedies to the identified harms (Table 2). Traditionally, private civil lawsuits have attempted to 'make whole' through direct restoration, replacement of damaged property, and/or by providing compensation based on the monetary value of the losses suffered by the plaintiff (e.g., related to injuries at work, car accidents, damaged property; Landes \& Posner, 1984). Developing lawsuits for harm to public goods such as biodiversity is more challenging, but the same legal concepts apply, with plaintiffs requesting remedies from defendants.

We highlight two broad approaches, and six possible methods to conceptualising harm to inform remedies (Table 3), which vary in adequacy of their response. For example, in the hypothetical orangutan case, the lawsuit might seek financial compensation based on proxies for total value, such as the animal's monetary value as a pet on the black market (Table 3, row 1), or a default value from the literature (row 3). However, such direct economic valuation of the harmed resource may not equate to meaningful remedy. For example, one orangutan's market value (whether hundreds or thousands of dollars) is a very poor reflection of its value as a critically endangered species. Alternatively, one could quantify the orangutan's value by identifying and valuing the ecosystem goods and services it provides (row 4). However, this approach can simultaneously be difficult to implement, particularly because data are lacking, and yield partial and uncertain results. These 
TA B L E 2 Types of harm incurred when biodiversity is injured. Each element of harm is described and given a concrete example from the orangutan scenario. Not all types of harm occur in each case, and not all jurisdictions recognize every type of harm in their legislation

\begin{tabular}{|c|c|c|}
\hline $\begin{array}{l}\text { Types of } \\
\text { harm }\end{array}$ & Description & Orangutan example \\
\hline \multicolumn{3}{|c|}{ Harm to the environment } \\
\hline & $\begin{array}{l}\text { Harm to individual plants, fungi or animals } \\
\text { affected by the case }\end{array}$ & - Injury to individual's wellbeing (physical and other) \\
\hline & Harm to species survival & $\begin{array}{l}\text { Reduction in survival probability of a Critically Endangered species when } \\
\text { reduced by one individual, especially a female of a slow reproducing } \\
\text { species. Even if reintroduced, it will not be into its original population. }\end{array}$ \\
\hline & $\begin{array}{l}\text { Harm to public ecosystem goods and services } \\
\text { and to broader human wellbeing }\end{array}$ & $\begin{array}{l}\text { - Reduced existence, intrinsic and bequest values, both domestically and } \\
\text { internationally } \\
\text { - Reduced ecotourism potential } \\
\text { - Losses for scientific research potential } \\
\text { - Impaired seed dispersal services }\end{array}$ \\
\hline
\end{tabular}

\section{Harm to the state}

Loss in state revenues

Loss in reputation and/or trust
- Reduced national park revenues

- Domestic and international reputational harm as trust in government's ability to conserve its protected species, effectively manage protected areas, and maintain control over illegal activities is reduced.

\section{Harm to private economic interests \\ Loss in income or property value \\ Increased private costs of accessing goods and - NA services}

\section{Extraordinary burdens of undertaking legal action to remedy harm}

- Administrative costs, such as DNA tests for genotyping and proving origin, required fieldwork and, hiring species experts

- Litigation costs associated with the public prosecutor or private lawyers.

- Court costs of ensuring their verdict/court order is enforced

limitations can present challenges for liability litigation, where demanding processes and scientific uncertainty can both create unintended barriers to justice (see Green et al., 2015), and overlook non-monetized values (Foster, 2007). Most pressingly, while these approaches might facilitate monetary compensation, they do not provide clear proposals for how the lawsuit could result in actions that meaningfully remedy harm to biodiversity.

In contrast to focusing on the monetary valuation, a more appropriate approach focuses on identifying the actions needed to fully remedy the harm, returning the harmed resource, insofar as possible, to baseline conditions. These are often referred to as actions to 'make the injured party whole' (see Mazzotta et al., 1994; Jones \& Di Pinto 2018). Once remedial actions are identified, a lawsuit can then request that the defendant undertake those actions, or cover the costs for an expert or government agency to undertake them, based on their procurement cost (row 5; Boyd, 2010). Environmental liability lawsuits, therefore, are best served if the focus is on the actions needed to remedy the affected ecosystems or species rather than placing a monetary value on nature itself.

A lawsuit can further seek restorative justice (row 6), requesting a defendant to undertake actions to make amends, such as issuing an apology, providing restitution or demonstrating generosity (Van Ness \& Strong, 2014). These remedies can sometimes serve to capture intangible impacts on human wellbeing, such as cultural losses and moral harm. Remedies can involve symbolic financial compensation, (e.g., for the social damage caused by corruption, Garcia et al., 2010). They can also involve nonfinancial, culturally embedded resolutions such as apologies (see Zwart-Hink et al., 2014). In some cases, remedies have also employed procurement costs in these contexts, such as the cost of developing a cultural site or educational program that remedies specific harms (e.g., development 

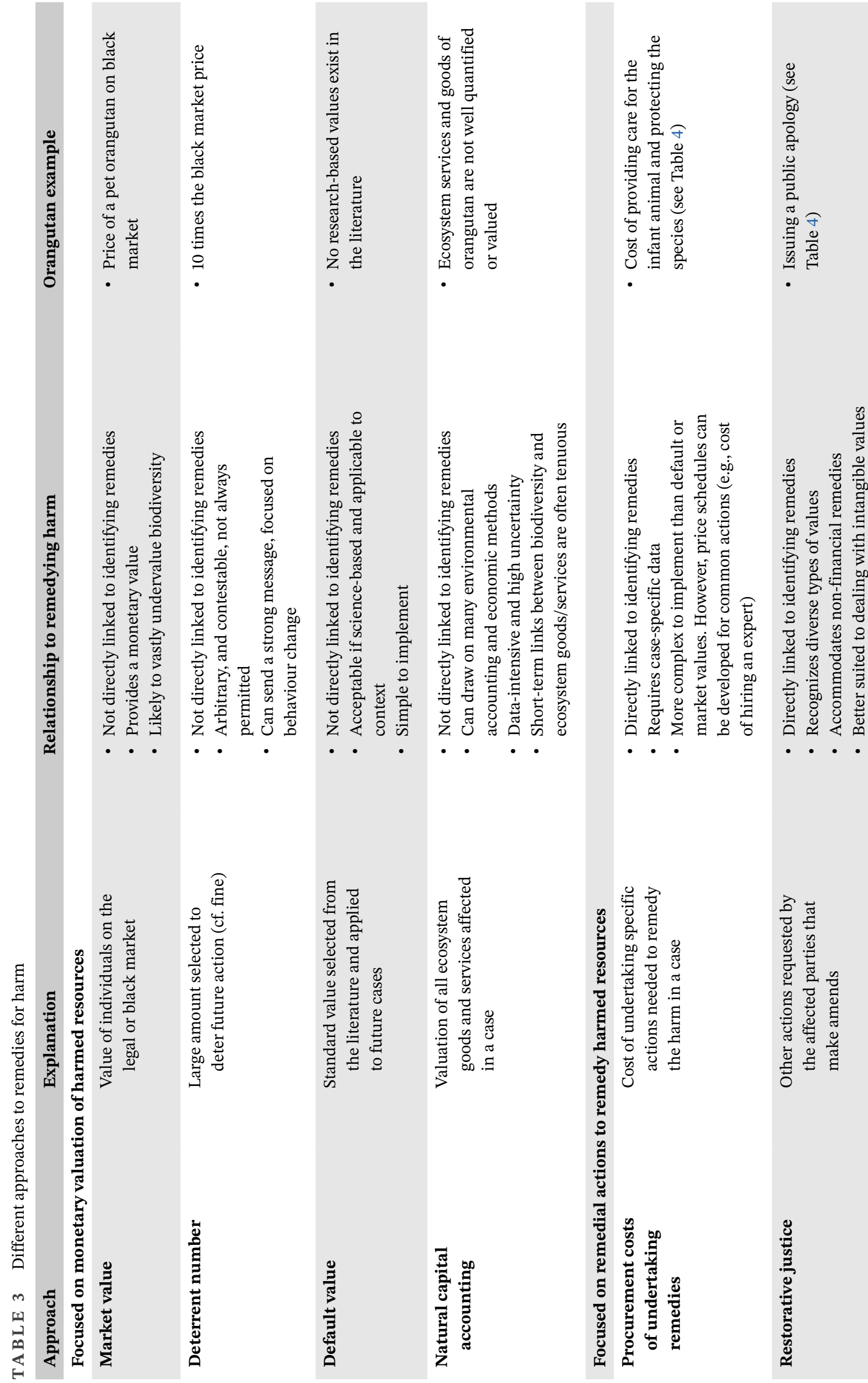
of a traditional medicinal plant garden on polluted indigenous land, Forde, 2014). These types of remedies can be more meaningful and deterrent than monetary compensation (Carroll \& Witzleb, 2011), especially in the context of diverse human-nature relationships.

By clearly identifying the harm incurred (Table 2), it is possible to assign appropriate remedial actions. We used this approach to identify remedies corresponding to different types of harm (Table 4; see Jones et al., 2015; Jones and Di Pinto 2018). As in the orangutan example, remedies can include the defendant undertaking actions themselves (e.g., apologies) and payments for others to undertake actions such as rehabilitation, protecting affected populations, and restoring habitat to enhance species recovery (Table 4). Notably, these can enable both non-financial remedies and compensation that carries financial implications orders of magnitude greater than criminal sanctions.

\section{4 | What will the law allow?}

Many countries allow lawsuits in response to many types of harm and to request diverse remedies available (Jones et al., 2015), possible under different areas of law across countries (e.g., Civil Code, specialized environmental law, but also administrative and criminal law). This allows litigation to explore the limits of liability, and so uses existing laws in new ways (Garmestani et al., 2019). Indeed, scholars and practitioners are already testing and re-shaping the boundaries of law in other contexts, including lawsuits over the harm caused by climate change (Setzer \& Vanhala, 2019). Nevertheless, legal factors circumscribe whether and how litigation may seek and receive legal remedies (see Fon \& Parisi, 2003; Rajamani, 2007). We highlight seven core legal constraints that shape lawsuit development (Table 5).

Litigation can only be pursued if the law in the relevant jurisdiction specifically includes liability for harm to biodiversity, or if existing law can be adapted to allow for such a lawsuit (legal basis, Table 5A). The scope of liability for harm is typically described in law, sometimes restricted to harm resulting from unlawful acts (e.g., illegal trade) but potentially also harm due to negligence, inaction, or legal activities that nevertheless caused injury or were inherently dangerous (e.g., handling toxic material). For example, the EU Environmental Liability Directive (2004, Art. 2.3) defines legally recognized harm as harm caused to protected species and natural habitats listed in the EU nature protection laws, with some states adopting more expansive domestic concepts of harm. Harm may also be limited based on the activity that caused it (Art. 3.1) and illegal trade is not currently an activity covered by the ELD. In contrast, Indonesia defines legally recognized harm based on whether harm exceed minimum thresholds (e.g., pollution standards) and can include harm caused by illegal trade.

Once the legal basis for litigation is established, the next steps involve determining whether the proposed plaintiff has a legal right to bring the lawsuit. This is a function of whether the country allows different types of stakeholders to bring suits (Table 5B, plaintiff standing). In some countries this right is reserved for government agencies acting on behalf of the public interest. Elsewhere, NGOs, individuals and groups affected by the case may also file lawsuits (Noble, 2002; Jones et al., 2015). These plaintiffs must usually have experienced an identifiable injury (Table 5C). This is typically a private injury, such as loss of income or reputation, but in some countries includes harm to the public interest, although this still requires a link between the plaintiff and the impairment of a right (Fogleman, 2013).

Moreover, the lawsuit must demonstrate causation between the defendant's action and the purported harm to the plaintiff (Table 5D). Those impact pathways must be clear and direct, which can be challenging in contexts of cumulative, non-linear, widespread or latent impacts (Faure, 2007). For example, the defendant in the orangutan case may be responsible for not only harming the individual animal, but also for impacts on overall species survival, an argument the lawsuit would need to make. Importantly, attribution science and socially accepted standards for what constitutes direct or proximate harm shift over time, including as a result of novel litigation - as occurred in the case of smoking cigarettes and cancer (e.g., Mather, 1998). Similar shifts may be possible for biodiversity through liability lawsuits.

The plaintiff must demonstrate that the proposed remedies appropriately and fairly address the harm (redressability, Table 5D). For example, although our hypothetical orangutan trader may be liable for harming species survival, they cannot be held responsible for the fate of the entire species. There may also be legal constraints on the types and scope of remedies that courts can order (Bergkamp, 2001), although this is typically defined by norms, and the number of approaches almost equals the number of authors discussing it (Persson, 2013). There are nevertheless often restrictions on the types of remedies that different plaintiffs can request. For example, in Indonesia, NGO plaintiffs can only request financial compensation for the out-of-pocket expenses they incurred as a result of the case (e.g., paying for orangutan rehabilitation), and may not seek to enrich themselves through the case. They can, however, request that the defendant undertake a wide range of actions to remedy harm (e.g., reforestation, apologies). 


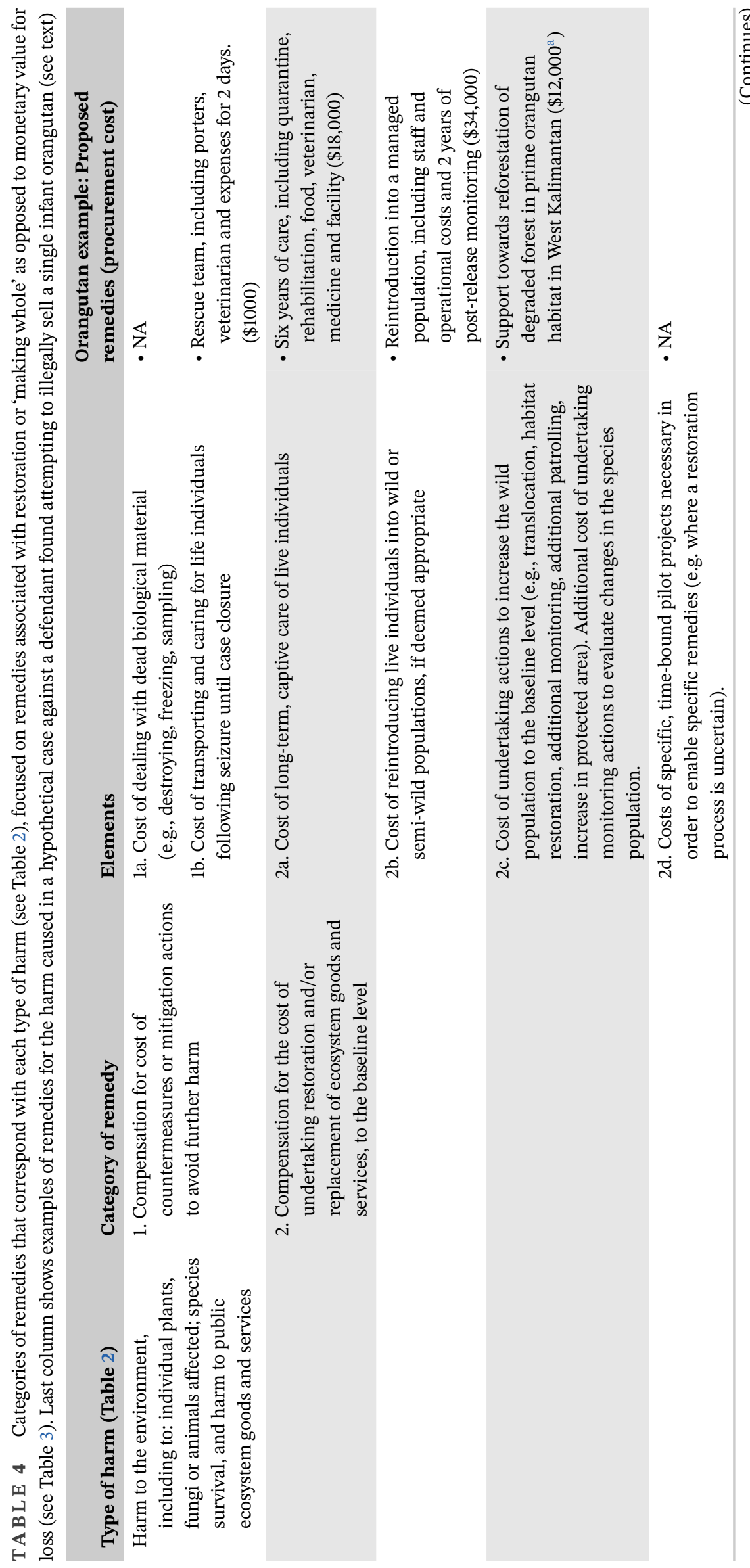




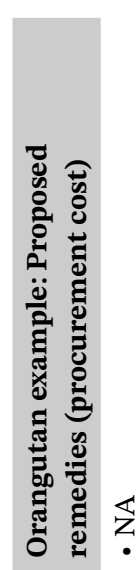

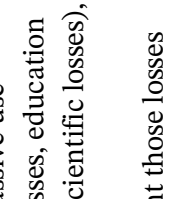

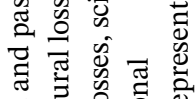
흔

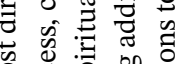

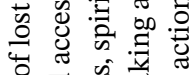

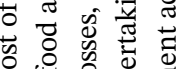

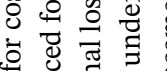
을 을 홀 ॠ

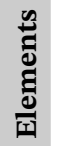

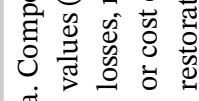
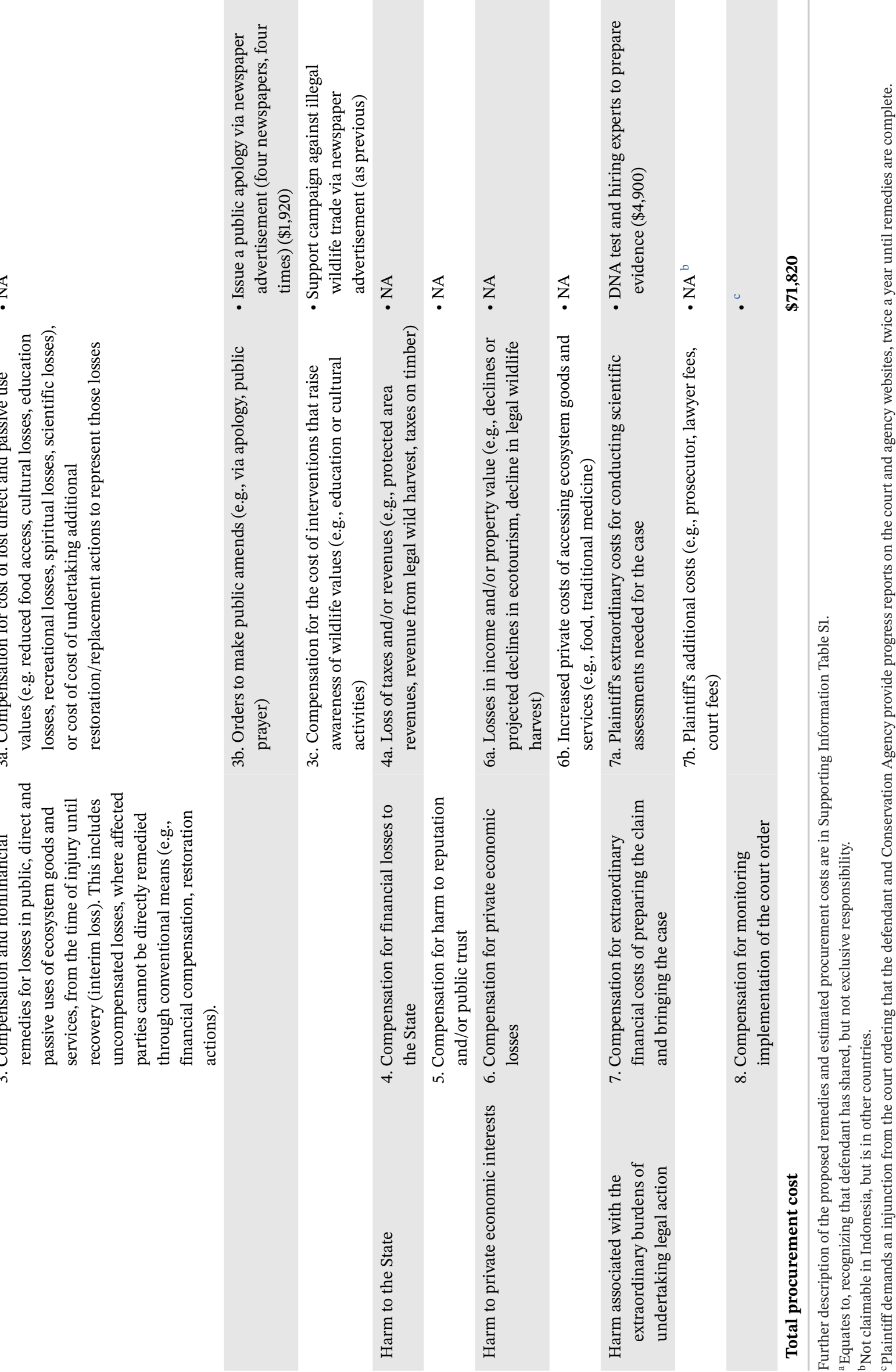


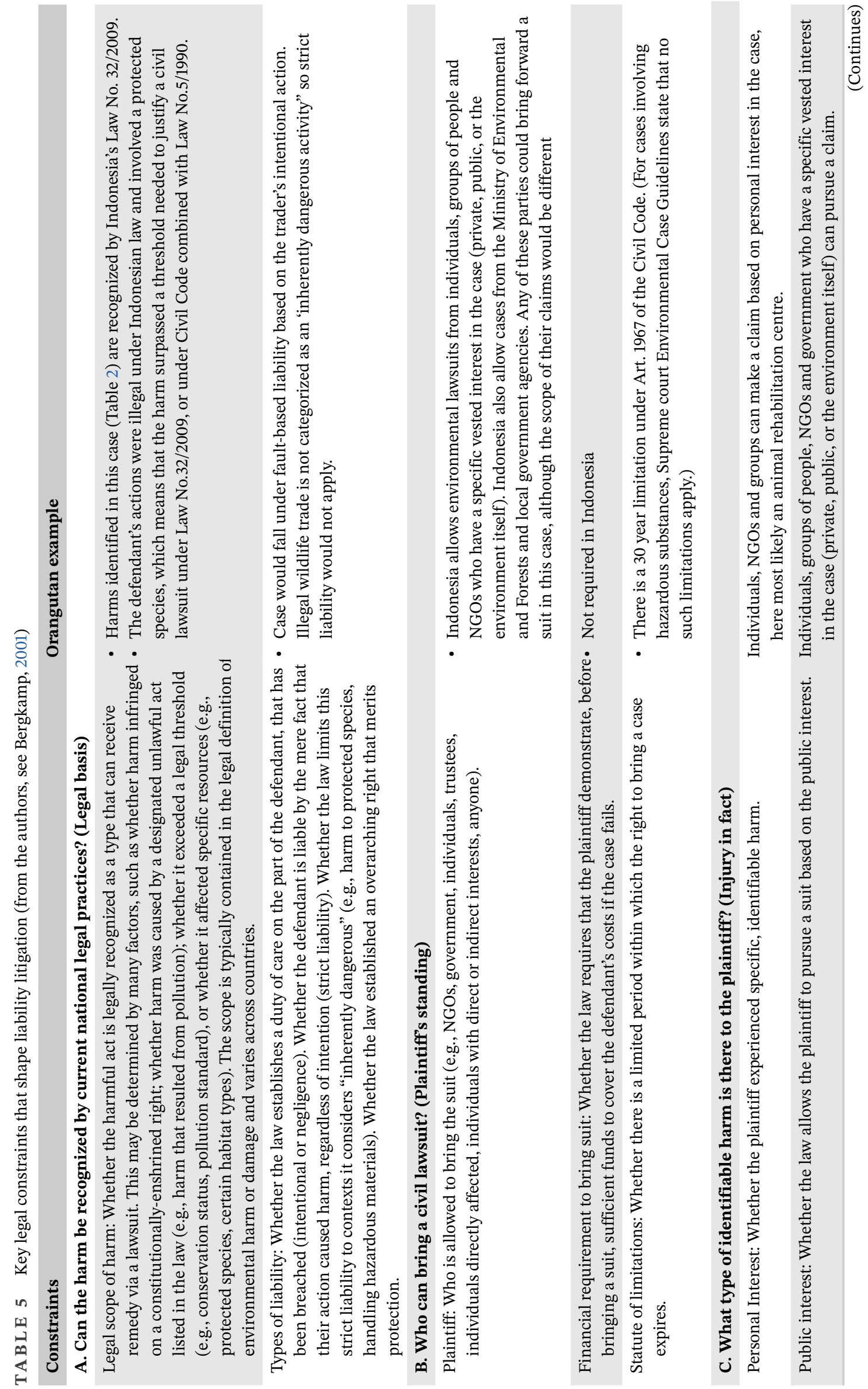




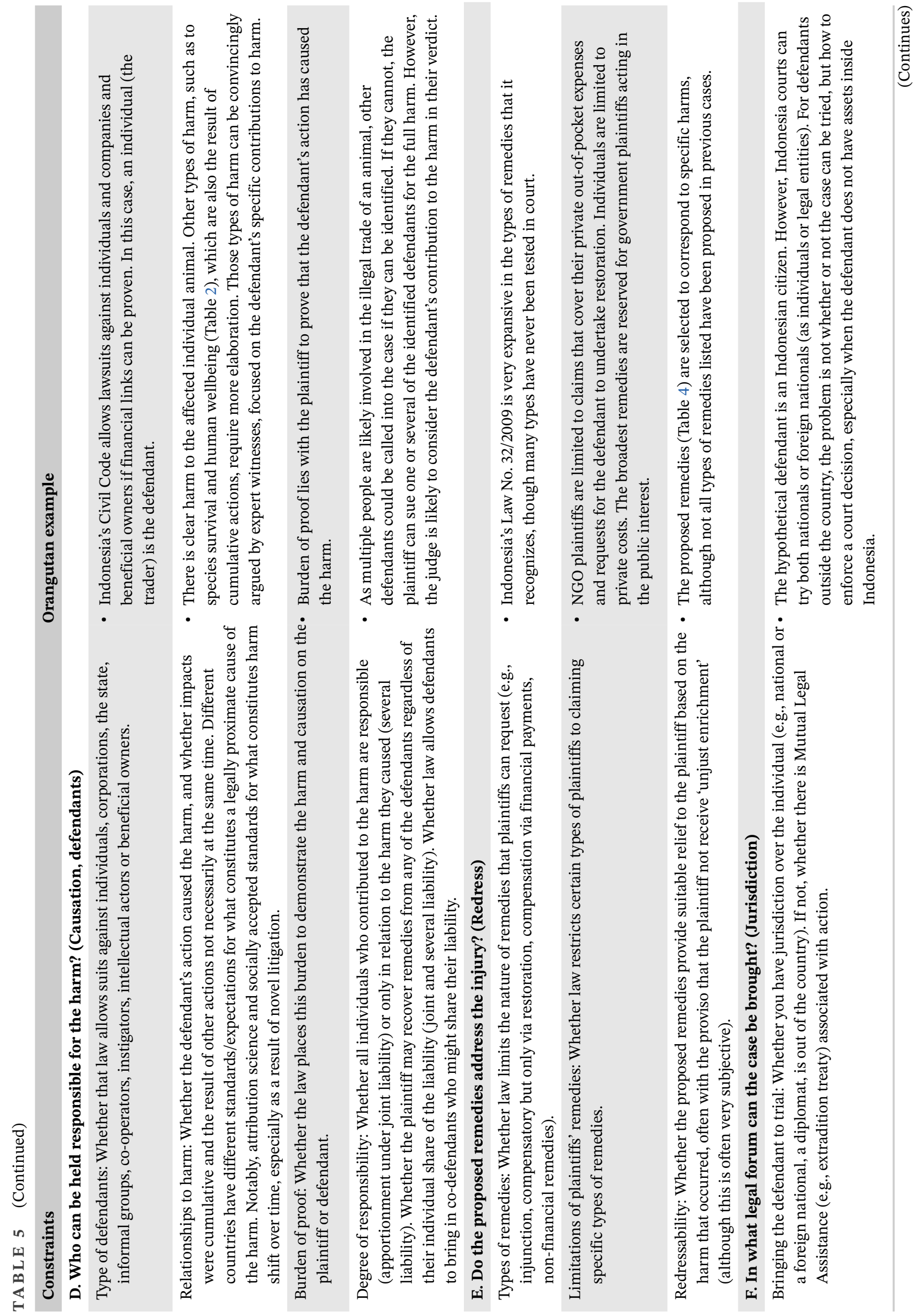




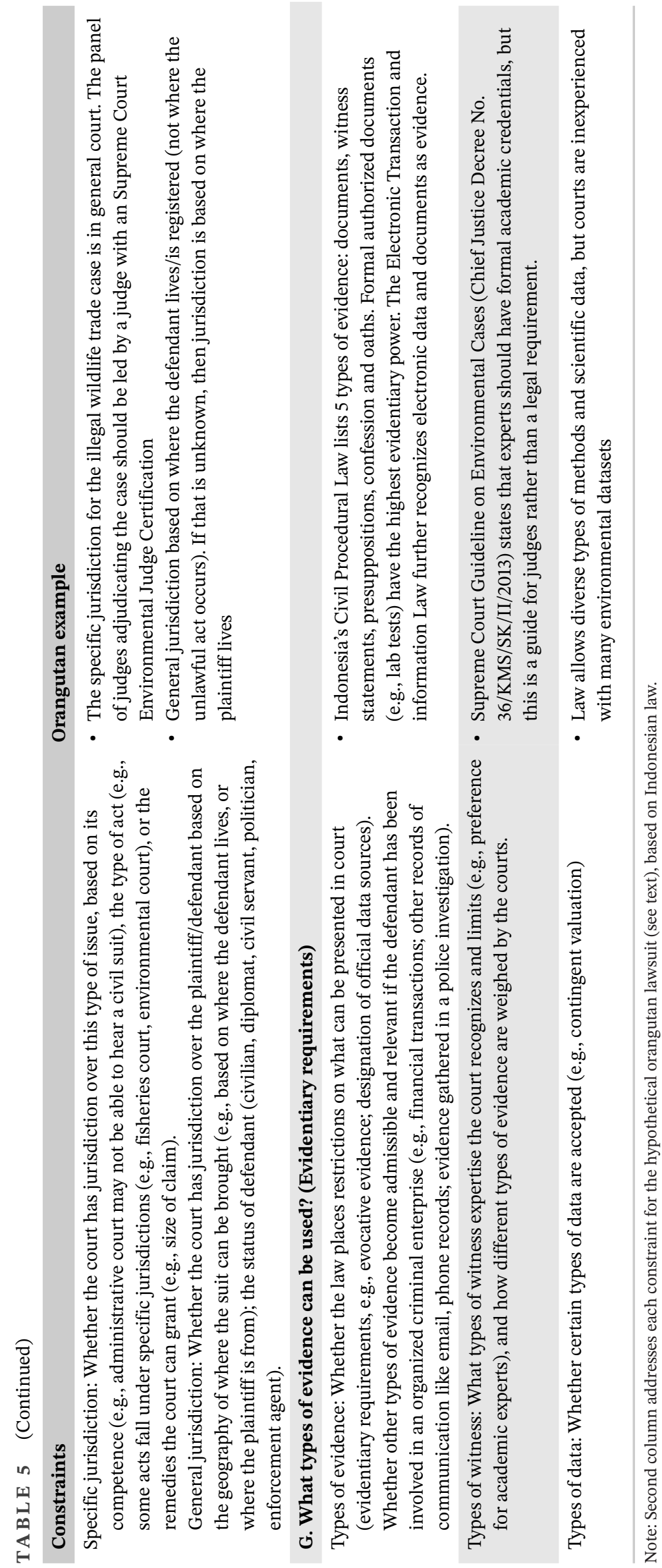


Liability litigation is constrained by the jurisdiction and legal forum where the case can be filed (Table 5F). Factors like the place where the harm occurred, the type of action, or the identity and status of the defendant can determine the court venue. There are also nuanced procedural requirements for what and how evidence is presented, including what types of evidence can be used, must be used (different burdens of evidence), and how it is presented (Table 5G).

In practice, litigation is also heavily shaped by legal, cultural, social and political norms (Peel \& Osofsky, 2015; Robinson, 2018). These can influence the types of cases likely to succeed in a given moment, and are shaped by advances in science and attribution, scientific consensus, public sentiment, and the court's willingness to accept various types of evidence, and grant certain types of remedies (Peel \& Osofsky, 2015). Importantly, pioneering litigation could shape these norms across much of the world.

\section{2 | CONCLUSION}

Environmental liability litigation offers potentially ground-breaking advances for safeguarding biodiversity, using legislation that already exists in many countries. The strategy remains a largely unexplored opportunity in many high-biodiversity countries, and is especially overlooked in its potential to address threats such as illegal wildlife trade. This is likely because liability litigation differs from the well-established approaches to conservation enforcement and involves complex legal technicalities with which most conservationists are inexperienced. Moreover, lawsuits can involve high transaction costs and technical barriers, lengthy court proceedings, and can offer uncertain returns for plaintiffs - all of which can discourage suits (Stech et al., 2009). The burdens on plaintiffs are exacerbated by violence against environmental activists, including those acting via the courts (Greenfield \& Watts, 2020). Moreover, as with other governance processes, court actions face widespread governance challenges that often affect how stated law is actually practiced (e.g., lax enforcement, corruption, resource and capacity limitations; Pinheiro et al., 2020). These barriers can impact which cases are litigated, how judges make decisions, and whether court orders and remedies are ever effectively executed on the ground.

Nevertheless, strategic litigation may challenge existing governance barriers and create new opportunities for conservation: placing new burdens on high-profile defendants in ways that may deter future harm; creating new pathways for environmental justice, funding conservation actions, and raising public awareness about the diverse values of nature. Importantly, in many countries, litigation offers opportunities and incentives for increased legal action - not only by the state, but also among citizens and NGOs, which is especially important in the context of weak government enforcement. Thus, there is a broad need to experiment with liability litigation across jurisdictions, notably in biodiversity hotspots where courtrooms may offer a forum of 'last resort' (see Rajamani, 2007). This would help legal systems and practitioners continue to learn, with new cases, court verdicts and experiences motivating both future lawsuits and progressive verdicts (see Fon \& Parisi, 2003).

Such developments would be impossible for lawyers or enforcement agencies alone, and require the engagement of conservation scholar-practitioners. It is valuable for ecologists and conservationists to recognize that their understanding of biodiversity, ecosystems and their links to human wellbeing is essential to define and characterize harm and identify corresponding remedies. Application of conservation knowledge in lawsuits is multifaceted, integrating both case-specific evidence and fundamental ecological principles into legal frameworks, as demonstrated in the orangutan example, which illustrates how future cases might be conceptualized across contexts. Conservationists have scope to bridge the gap between their sciences and the law, proactively reaching out to lawyers, investigators, NGOs and various plaintiffs in high-biodiversity countries to develop lawsuits. Conservation science is thus a core component of a strategic science-based approach to litigation that identifies priority contexts, targets defendants responsible for egregious harm, works within favorable legal systems, proposes novel and deterrent remedies, and builds new transdisciplinary collaborations.

\section{ACKNOWLEDGEMENTS}

Funded by the UK Government through the Illegal Wildlife Trade Challenge Fund. Thank you to the Glass Family of Low Annat Walls, Andri Gunawan, Bambang Hero, Rosa Agustina, Arif Yogiawan, Rasio Ridho Sani, International Animal Rescue Indonesia, Indonesia's Directorate General of Law Enforcement, Ministry of Environment and Forestry, and the Natural Resource Conservation Unit Offices of West Kalimantan and North Sumatra.

\section{AUTHOR CONTRIBUTIONS}

All of the authors contributed to conceptualizing and writing the article. 


\section{ETHICS STATEMENT}

No institutional ethics review was required for this article. The work was conducted under a Foreign Research Permit for J.Phelps from Indonesia's Ministry of Research, Technology, and Higher Education.

\section{CONFLICT OF INTEREST}

The authors declare no conflict of interest.

\section{DATA ACCESSIBILITY STATEMENT}

There is no additional data set associated with this article.

\section{REFERENCES}

(BIOVAL) Ecosystems Recovery Calculation. (2021). European Union network for the implementation and enforcement of environmental law, European Union Forum of Judges for the Environment, European Network of Prosecutors for the Environment. KU Leuven. https://www.impel.eu/projects/ bioval-ecosystems-recovery-calculation/

Bentata, P., \& Faure, M. G. (2012). The role of environmental civil liability: An economic analysis of the French legal system. Environmental Liability, Law, Policy and Practice, 20, 120-128. https: //doi.org/10.2139/ssrn.2334621

Bergkamp, L. (2001). Liability and environment: Private and public law aspects of civil liability for environmental harm in an international context. Martinus Nijhoff Publishers.

Boyd, J. W. (2010). How do you put a price on marine oil pollution damages? Resources, 175, 21-23.

Brisman, A., \& South, N. (2019). Green criminology and environmental crimes and harms. Sociology Compass, 13, e12650. https: //doi.org/10.1111/soc4.12650

Brosi, B. J., \& Biber, E. G. (2012). Citizen involvement in the US Endangered species Act. Science, 337, 802-803. https://doi.org/10. 1126/science.1220660

Carroll, R., \& Witzleb, N. (2011). It's not just about the moneyenhancing the vindicatory effect of private law remedies. Monash University Law Review, 37, 216-240.

Cohen, M. A. (1991). Environmental crime and punishment: Legal/economic theory and empirical evidence on enforcement of federal environmental statutes. Journal of Criminal Law and Criminology, 82, 1054-1108.

Cruden, J. C., O’Rourke, S., \& Himmelhoch, S. D. (2016). The Deepwater Horizon oil spill litigation: proof of concept for the manual for complex litigation and the 2015 amendments to the federal rules of civil procedure. Michigan Journal of Environmental and Administrative Law, 6, 65-147.

Díaz, S., Settele, J., Brondízio, E., Ngo, H., Guèze, M., Agard, J., Arneth, A., Balvanera, P., Brauman, K. A., Butchart, S. H. M., Chan, K. M. A., Garibaldi, L. A., Ichii, K., Liu, J., Subramanian, S. M., Midgley, G. F., Miloslavich, P., Molnár, Z., Obura, D., ... Zayas, C. N. (2020). Summary for policymakers of the global assessment report on biodiversity and ecosystem services. IPBES Secretariat.

EU Environmental Liability Directive (2004). Directive 2004/35/CE of the European Parliament and of the Council of 21 April
2004 on environmental liability with regard to the prevention and remedying of environmental damage. OJ L 143, 30.4.2004, p. 56-75.

Faure, M. (2007). L'analyse économique du droit de l'environnement. Bruylant.

Fogleman, V. (2013). The study on analysis of integrating the ELD into 11national legal frameworks. Final Report prepared for the European Commission - DG Environment. Stevens \& Bolton LLP.

Foster, J. (Ed.) (2007). Valuing nature? Economics, ethics, and environment. Routledge.

Fon, V., \& Parisi, F. (2003). Litigation and the evolution of legal remedies: A dynamic model. Public Choice, 116, 419-433. https://doi.org/ 10.1023/A:1024822710849

Forde, K. (2014, June 16). Ford pays for Ramapough Tribe medicine garden on former toxic site. Aljazeera America. http://america. aljazeera.com/articles/2014/6/16/ramapough-ford-toxic.html

Garcia, J. O., Attisso, K., \& Roth, A. (2010). Repairing social damage out of corruption cases: Opportunities and challenges as illustrated in the Alcatel case in Costa Rica. http://doi.org/10.2139/ssrn. 1779834

Gordon, G. (2018). Environmental personhood. Columbia Journal of Environmental Law, 43, 49-91.

Garmestani, A., Ruhl, J. B., Chaffin, B. C., Craig, R. K., van Rijswick, H. F., Angeler, D. G., Folke, C., Gunderson, L., Twidwell, D., \& Allen, C. R. (2019). Untapped capacity for resilience in environmental law. Proceedings of the National Academy of Sciences, 116, 19899-19904. https://doi.org/10.1073/pnas.1906247116

Green, O. O., Garmestani, A. S., Allen, C. R., Gunderson, L. H., Ruhl, J. B., Arnold, C. A., Graham N. A. J., Cosens B., Angeler D. G., Chaffin B. C., \& Holling, C. S. (2015). Barriers and bridges to the integration of social-ecological resilience and law. Frontiers in Ecology and the Environment, 13, 332-337. https://doi.org/10.1890/ 140294

Greenfield, P., \& Watts, J. (2020, July 29). Record 212 land and environment activists killed last year. The Guardian. https://www.theguardian.com/environment/2020/jul/29/ record-212-land-and-environment-activists-killed-last-year

Hinsley, A., Entwistle, A., \& Pio, D. V. (2015). Does the long-term success of REDD+ also depend on biodiversity? Oryx, 49, 216-221. https://doi.org/10.1017/S0030605314000507

Johnson, E. W., Schwartz, J., \& Inlow, A. R. (2020). The criminalization of environmental harm: a study of the most serious environmental offenses prosecuted by the US federal government, 19852010. Environmental Sociology, 6, 1-15. https://doi.org/10.1080/ 23251042.2020.1748269

Jones, C. A., \& DiPinto, L. (2018). The role of ecosystem services in USA natural resource liability litigation. Ecosystem Services, 29, 333-351. https://doi.org/10.1016/j.ecoser.2017.03.015

Jones, C. A., Pendergrass, J., Broderick, J., \& Phelps, J. (2015). Tropical conservation and liability for environmental harm. Environmental Law Reporter, 45, 11032-11050.

Landes, W. M., \& Posner, R. A. (1984). Tort law as a regulatory regime for catastrophic personal injuries. The Journal of Legal Studies, 113, 417-434.

Marseille (2020). Cour Correctionnelle [CC][Regional First Instance Court], Marseille, crim., Mar. 6, 2020.

Mather, L. (1998). Theorizing about trial courts: Lawyers, policymaking, and tobacco litigation. Law \& Social Inquiry, 23, 897-940. https://doi.org/10.1111/j.1747-4469.1998.tb00037.x 
Mazzotta, M. J., Opaluch, J. J., \& Grigalunas, T. A. (1994). Natural resource damage assessment: the role of resource restoration. Natural Resources Journal, 34, 153-178.

Noble, J. M. (2002). Friends of the Earth v. Laidlaw and the increasingly broad standard for citizen standing to sue in environmental litigation. Natural Resources Journal, 42, 415-432.

Peel, J., \& Osofsky, M. (2015). Climate change litigation: Regulatory pathways to cleaner energy. Cambridge University Press.

Persson, J. (2013). Perceptions of environmental compensation in different scientific field. International Journal of Environmental Studies, 70, 611-628. https://doi.org/10.1080/00207233.2013.835526

Phelps, J., Jones, C. A., \& Pendergrass, J. (2019). Liability for environmental harm as a response to the Anthropocene. In M. Lim (Ed.), Charting environmental law futures in the Anthropocene (pp. 171180). Springer.

Phelps, J., Jones, C. A., Pendergrass, J. A., \& Gómez-Baggethun, E., (2015). Environmental liability: A missing use for ecosystem services valuation. Proceedings of the National Academy of Sciences, 112, E5379-E5379. https://doi.org/10.1073/pnas.1514893112

Pinheiro, M. V., Sánchez, M. R., Long, S. C., \& Ponce, A. (2020). Environmental governance indicators for Latin America \& the Caribbean: A cross-country assessment of environmental governance in practice in Argentina, Bolivia, Brazil, Colombia, Costa Rica, the Dominican Republic, El Salvador, Jamaica, Peru \& Uruguay. Inter-American Development Bank, World Justice Project.

Rajamani, L. (2007). Public interest environmental litigation in India: Exploring issues of access, participation, equity, effectiveness and sustainability. Journal of Environmental Law, 19, 293-321. https: //doi.org/10.1093/jel/eqm020

Robinson, N. A., (2018). The nature of courts. In C. Voigt \& Z. Makuch (Eds.), Courts and the environment (pp. 2-34). Edward Elgar Publishing.

Ruda González, A. (2006). El daño ecológico puro. La responsabilidad civil por el deterioro del medio ambiente. Universitat de Girona.

Setzer, J., \& Vanhala, L. C. (2019). Climate change litigation: A review of research on courts and litigants in climate governance. Wiley Interdisciplinary Reviews: Climate Change, 10, e580. https://doi. org/10.1002/wcc.580

Stech, R., Lee, R., \& Tripley, D. (2009). Costs barriers to environmental justice: $A$ report in association with business relationships, accountability, sustainability and society centre. Environmen- tal Law Foundation. https://unece.org/fileadmin/DAM/env/pp/ compliance/C2008-33/correspondence/FrELF_Report2009.pdf

(UK) UK Government. (2019). Illegal Wildlife Trade Conference: London, UK, 11-12 October, 2018. https://www.gov.uk/ government/topical-events/london-conference-on-the-illegalwildlife-trade2018

Van Ness, D. W., \& Strong, K. H. (2014). Restoring justice: An introduction to restorative justice. Routledge.

(WCS) Wildlife Conservation Society. (2020). Combatting wildlife trafficking. https:/www.wcs.org/our-work/solutions/ combating-wildlife-trafficking

White, R., \& Heckenberg, D. (2011). Environmental horizon scanning and criminological theory and practice. European Journal of Criminal Policy and Research, 17, 87-100. https://doi.org/10.1007/ s10610-011-9138-y

Whitehead, A. L., Kujala, H., \& Wintle, B. A. (2017). Dealing with cumulative biodiversity impacts in strategic environmental assessment: A new frontier for conservation planning. Conservation Letters, 10, 195-204. https://doi.org/10.1111/conl.12260

Wilson, L., \& Boratto, R. (2020). Conservation, wildlife crime, and tough-on-crime policies: Lessons from the criminological literature. Biological Conservation, 251, 108810. https://doi.org/10.1016/ j.biocon.2020.108810

Zwart-Hink, A., Akkermans, A., \& van Wees, K. (2014). Compelled apologies as a legal remedy: Some thoughts from a civil law jurisdiction. University of Western Australia Law Review, 38, 123-142.

How to cite this article: Jacob Phelps, Sakshi Aravind, Susan Cheyne, Isabella Dabrowski Pedrini, Rika Fajrini, Carol A. Jones, Alexander C. Lees, Anna Mance, Grahat Nagara, Taufiq P. Nugraha, John Pendergrass, Umi Purnamasari, Maribel Rodriguez, Roni Saputra, Stuart P. Sharp, Amir Sokolowki, Edward L. Webb. Environmental liability litigation could remedy biodiversity loss. Conservation Letters. 2021;e12821. https://doi.org/10.1111/conl.12821 